\title{
Substance Use Across Adolescence: Do Gender and Age Matter?
}

\section{Consumo de Substâncias na Adolescência: O Género e a Idade são Importantes?}

\author{
Celeste Simões ${ }^{*}, a$, Margarida Gaspar Matos $^{a}$, Joan M. Batista-Foguet ${ }^{b}$ \& Bruce Simons-Morton ${ }^{c}$ \\ ${ }^{a}$ Universidade de Lisboa, Lisboa, Distrito de Lisboa, Portugal \\ ${ }^{b}$ Universitat Ramon Llull, Barcelona, España \\ $\&^{c}$ National Institute of Child Health and Human Development, Bethesda, Maryland, USA
}

\begin{abstract}
Many of the choices which impact in lifetime health, such as substance use, are made in adolescence. It becomes, therefore, important to know the factors associated to these behaviours in adolescence in different contexts of life. To analyze these factors, an explanatory model was developed using structural equation modeling. Data from 12.881 state school students from Portugal who participated in two waves of the Health Behaviours in School-aged Children (HBSC) / World Health Organization (WHO) survey were analyzed. The model fits well the data [CFI: .985; NNFI: .980; RMSEA: .018 (.017-.020); SRMR: .018]. For each of the dependent factors, the levels of variance ranged from $12 \%$ (tobacco use) to $47 \%$ (alcohol and illicit drugs use). Alcohol and tobacco present the strongest associations to illicit drugs use. Relationships with family, friends, classmates, and teachers were also associated with substance use, being this association mediated by certain factors, including psychological symptoms, well-being, and school satisfaction. Several non-invariant paths were obtained in gender and age comparisons. The results showed that substance use is associated with several factors and that social factors are mediated by personal factors. Results have also shown that gender and age are important factors on substance use.

Keywords: Adolescents, substance use, gender and age differences.
\end{abstract}

\begin{abstract}
Resumo
Muitas das escolhas com impacto na saúde a longo prazo, como o consumo de substâncias, são feitas na adolescência. Torna-se pois importante conhecer os fatores associados a estes comportamentos em diferentes contextos de vida. Para analisar estes fatores, foi desenvolvido um modelo explicativo através da modelação de equações estruturais. Para este estudo foram analisados dados de 12881 alunos de escolas públicas participantes em duas recolhas do estudo HBSC/OMS. O modelo apresenta uma boa adequação [CFI..985; NNFI:.980; RMSEA:.018 (.017-.020); SRMR:.018]. Para cada um dos fatores dependentes, os níveis de variância explicada variaram entre 12\% (tabaco) e 47\% (álcool e drogas ilícitas). Os consumos de álcool e tabaco apresentaram as associações mais fortes com o consumo de drogas ilícitas. As relações com a família, amigos, colegas e professores estão associadas ao consumo de substâncias, sendo esta associação mediada por vários fatores, nomeadamente sintomas psicológicos, bem-estar, e satisfação com a escola. Ligações não-invariantes foram obtidas nas comparações de género e idade. Os resultados mostraram que o consumo de substâncias está associado a vários fatores, e que o impacto dos fatores sociais é mediado por fatores pessoais. Os resultados mostraram ainda que o género e a idade são fatores importantes no consumo de substâncias. Palavras-chave: Adolescentes, consumo de substâncias, diferenças de género e idade.
\end{abstract}

Substance use is a behaviour that threatens the health and well-being of adolescents (Dahl, 2004; D'Amico et al., 2005). Among the many factors associated with adolescent substance use, social contextual factors invol- ving family, peers, and teachers have been identified as important. In general, social relationships in the main life contexts of family, peer group, and school, are protective against threats to adolescent well-being (Huver, Engels,
* Mailing address: Faculdade de Motricidade Humana, Universidade de Lisboa, Estrada da Costa, Cruz Quebrada, Portugal 1495-688. E-mail: csimoes@fmh.ulisboa.pt, mmatos@fmh.ulisboa.pt, joanm.batista@esade.edu e mortonb@mail.nih.gov

The authors would like to thank the Portuguese Health Behaviour In School-Aged Children (HBSC) team -

"Aventura Social" - for their work on collection and data management. The Portuguese HBSC study was funded in the first wave by the Projecto Vida, Programa de Educação Para Todos (PEPT) Saúde and Gabinete de Prevencão da Toxicodependência /Câmara Municipal de Lisboa (GPT/CML) and in the second wave by Fundação para a Ciência e a Tecnologia/Ministério da Ciência, Tecnologia e Ensino Superior (FCT/MCES; POCTI-37486/ PSI/2001), and PSIDA/PSI/49649/ 2003. 
Van Breukelen, \& de Vries, 2007; Simons-Morton, 2007). Good relationships facilitate well-being (Argyle, 1997) and discourage substance use (Otten, Van de Ven, Engels, \& Van den Eijnden, 2009), while poor relationships increase the risk for adjustment problems and substance use (Whalen, Jamner, Henker, \& Delfino, 2001).

The family has a fundamental role in child and adolescent development (Braconnier \& Marcelli, 2000; Steinberg, 2001). Notably, emotional support, supervision, and communication between parents and adolescents are key elements of adolescent adjustment (Huver et al., 2007; Weitoft, Hjern, Haglund, \& Rosen, 2003).

Peer-group affiliation is particularly important and influential during adolescence (Sprinthall \& Collins, 1999; Tomé, Camacho, Matos, \& Diniz, 2011). Norms with respect to substance use and other behaviours are greatly influenced by peer group and close friends (Simons-Morton \& Chen, 2009; Spijkerman, Van den Eijnden, Overbeek, \& Engels, 2007).

Teachers and the classmates are important to social well-being and adjustment to school (Torsheim \& Wold, 2001). Several studies show that the support and acceptance of classmates is positively related to well-being (Feitosa, Matos, Del Prette, \& Del Prette, 2005; Tomé et al., $2011)$ and negatively related to psychological symptoms (Torsheim \& Wold, 2001). Moreover, good attachment with teachers who provide support, advice, and affection is important for well-being and school adjustment (Werner \& Smith, 2001) and school connectedness discourages substance use and fosters well-being (Matos \& Equipa do Projecto Aventura Social, 2003; Simões et al., 2012). Sex and age are important developmental contributions to adolescent health (Borges, Matos, \& Diniz, 2011; Grogan, Conner, Fry, Gough, \& Higgins, 2009; Matos et al., 2006). In general, substance use prevalence is higher among boys than girls and higher among older than younger adolescents (Currie et al., 2008; Hibell et al., 2009) although there is evidence that the gender gap may be declining (SimonsMorton et al., 2009). Notably, girls may be more reactive to interpersonal conflicts with parents or peers compared with boys and this conflict is associated with risk for depressive symptoms (Rudolph \& Hammen, 1999). Also, girls have more conflicts in peer relations, are more vulnerable to peer rejection (Oldenburg \& Kerns, 1997), and may be more susceptible to peer influence compared with boys (Carli, 1989; Coleman, 1985). The importance of peer relationships appears to vary during adolescence, and there is some evidence that peer effects are most important for positive behaviour among younger adolescents and negative behaviour among older adolescents (Coleman, 1985; Settertobulte, 2000).

Ultimately, interactions between environmental and individual factors influence adolescent substance use (Igra \& Irwin, 1996; Udry, 1994). The literature suggests that positive relations with family, peers, classmates and teachers may provide protective effects against substance use through their positive influence on well-being and school satisfaction. While attitudes are greatly influenced by social relationships they may also moderate the effect of relationships on substance use (Beauvais \& Oetting, 1999).

Considerations about social contexts and relationships among adolescent boys and girls were the bases for the development of a substance use explicative model. In an attempt to provide a "global picture", rather than considering the various relations separately, the model was designed to establish connections between the social relationship variables and substance use and their mediation by individual intervening variables.

According to this model, adolescents' social contexts and relationships impact individual perceptions of well-being and school satisfaction, considered to be intervening factors, which, in turn, influence the outcomes of interest, adolescent substance use. Specifically, we expect that: (a) Easy communication with family and friends and positive relationships with classmates and teachers will be positively associated with subjective well-being and school satisfaction and negatively associated with psychological symptoms; (b) Psychological symptoms will be negatively associated with subjective well-being and school satisfaction, and positively associated with substance use (tobacco, alcohol and illicit drugs); (c) School satisfaction will be positively associated with well-being and negatively associated with substance use; (d) Subjective well-being will be negatively associated with substance use.

To assess the unique relationships of social context variables in substance use and the moderate effect of gender and age on these relations, analytic models tested for four different groups of respondents: younger boys, younger girls (11-14 years old); older boys, and older girls (15-18 years old).

\section{Method}

Data from two waves of the Portuguese HBSC study (Matos \& Equipa do Projecto Aventura Social, 2003; Matos, Simões, Carvalhosa, Reis, \& Canha, 2000), a collaborative WHO study (Currie, Smith, Boyce, \& Smith, 2001 ), were analysed. To obtain a representative sample of Portuguese students in grades $6^{\text {th }}, 8^{\text {th }}$ and $10^{\text {th }}$ were recruited from $191\left(1^{\text {st }}\right.$ wave $)$ and $135\left(2^{\text {nd }}\right.$ wave $)$ randomly selected schools from the 1,535 Portuguese state schools (Madeira and the Azores not included) using cluster sampling with class as the basic sampling unit. Ultimately, 331 classes ( $1^{\text {st }}$ wave) and 374 classes ( $2^{\text {nd }}$ wave) were selected, providing a sample of 14234 students. Data were collected through anonymous self-completion questionnaires administered in the classroom by teachers (details about the survey procedures can be found in Roberts, Tynjälä, Currie, \& King, 2004). The main HBSC survey included questions on demographics (age, gender, socio-demographics), school related variables, substance use, physical activity and leisure, nutrition, safety, psychosocial health, general health symptoms, social relations and social support. 
Simões, C., Matos, M. G., Batista-Foguet, J. M. \& Simons-Morton, B. (2014). Substance Use Across Adolescence: Do Gender and Age Matter?

\section{Measures}

For the present study 27 variables conceptually linked to 10 factors were selected. The indicators of the ten factors model were:

1. Family (father/ mother communication: $1=$ don't have or see this person; $2=$ very difficult; $3=$ difficult; 4=easy; $5=$ very easy);

2. Friends (same gender friends/ opposite gender friends communication: $1=$ don't have or see this person; 2=very difficult; 3=difficult; 4=easy; $5=$ very easy; easy to make new friends: $1=$ very difficult; $2=$ difficult; $3=$ easy; 4=very easy; and time with friends after school: $1=$ don't have friends; $2=$ once or less; 3=2-3 times; 4=4-5 times);

3. Classmates (enjoy being together, are kind and helpful, accept me as I am: 1=strongly disagree; $2=$ disagree; $3=$ neither agree or disagree; $4=$ agree; $5=$ strongly agree);

4. Teachers (treat us fairly, encouraged to express my own views in class, help when I need, are interested in me as person: $1=$ strongly disagree; $2=$ disagree; $3=$ neither agree or disagree; $4=$ agree; $5=$ strongly agree);

5. Psychological symptoms (feeling low, irritability or bad temper, feeling nervous: $1=$ rarely or never; 2 =about every month; $3=$ =about every week; $4=$ more than once a week; $5=$ about every day);

6. Subjective well-being (health: $1=$ poor; 2 =fair; $3=$ good; 4= excellent; and happiness: 1=unhappy; 2=not very happy; 3=happy; 4=very happy);

7. School satisfaction (feel about school: $1=$ don't like it at all; $2=$ don't like very much; 3=I like a bit; 4=I like a lot; school is boring: 1=always; $2=$ frequently; $3=$ sometimes; 4=rarely; 5=never; and feeling safety in school: $1=$ never; $2=$ rarely; 3 =sometimes; 4=frequently; 5=always);

8. Tobacco $(1=\mathrm{I}$ do not smoke; $2=$ less than once a week; $3=$ at least once a week; $4=$ every day);

9. Alcohol use (beer and spirits consumption: $1=$ never; $2=$ rarely; $3=$ every month; $4=$ =very week; $5=$ every day; and been drunk: $1=$ never; $2=$ once; $3=2-3$ times; $4=4-10$ times; $5=$ more than 10 times);

10. Illicit drugs use (tried marijuana: $1=$ no; $2=y e s ;$ and illicit drug use last month: $1=$ never; $2=$ one time; $3=$ more than one time; $4=$ regular consumption).

\section{Data Analysis}

Structural Equations Modelling, EQS Structural Equation Modelling Software (Bentler, 1995) was used to analyse the proposed model. Robust estimation was used for all analysis. Variables were transformed as needed to continuous variables through optimal scaling. To control for the latent variables being adequately measured, a confirmatory factorial analysis was conducted prior to running the global model. For the proposed model, three measurement models were tested: the "independent latent factors model" that tested the measurement quality of independent latent variables (family, friends, classmates and teachers); the "intervening latent factors model" that tested the measurement quality of intervening measurement variables (psychological symptoms, subjective well-being and school satisfaction), and the "dependent latent factors model" that tested the measurement quality of dependent variables (tobacco, alcohol and illicit drugs use).

After testing each of the measurement models, the global model was tested initially for the whole sample and then for four different groups: younger boys, younger girls, older boys, and older girls. The multi-group comparisons enabled the introduction of exogenous categorical variables in structural equations models (Reise, Widaman, \& Pugh, 1993). Several analyses were undertaken to confirm factorial invariance (configural and metric) between the four groups for each of the three measurement models. Firstly these analysis were undertaken for the four groups simultaneously and then with two groups (for the dependent measurement model, since invariance wasn't verified in the analysis with the four groups). After this step, multi-group comparisons of the structural model were conducted. Two analyses were run to test gender differences (controlling for age), one between younger boys and younger girls and the other between older boys and older girls. Two other analyses were run to test age comparisons (controlling for gender) between younger boys and older boys and between younger girls and older girls.

\section{Results}

Of the 13434 questionnaires received, 553 (4.1\%) were excluded because of missing data on variables such as gender or age. The final sample included 12881 adolescents. Respondents were 11 to 18 years old ( $M=14$ years, $S D=$ 1.77 years). Of these, $48 \%$ were boys and $52 \%$ girls. For grade levels, $36.8 \%$ attended the $6^{\text {th }}$ grade, $36.6 \%$ were in the $8^{\text {th }}$ grade and $26.6 \%$ were in the $10^{\text {th }}$ grade.

\section{Structural Model}

The fit indices held in the analysis for the global model were good $\left[\chi^{2}=1270.02(173), p<.001 ; \mathrm{CFI}=.978\right.$; $\mathrm{NNFI}=.971 ; \mathrm{RMSEA}=.022 ; \mathrm{SRMR}=.024]$. Nevertheless, LM test showed that introducing paths between friend's factor and both tobacco and alcohol factors would significantly decrease the chi-square value. Since these paths are often mentioned in literature, they were introduced and the model was analysed again $\left[\chi^{2}=941.98(171), p<.001\right.$; $\mathrm{CFI}=.985 ; \mathrm{NNFI}=.979$; $\mathrm{RMSEA}=.019 ; \mathrm{SRMR}=.018]$. Finally, Wald Test showed that five model paths were non-significant, including the paths between friends and subjective well-being, subjective well-being and alcohol, subjective well-being and illicit drugs, school satisfaction and illicit drugs, and classmates and school satisfaction. The final model showed a good fit $(\mathrm{CFI}=.985$; NNFI $=.980$; $\mathrm{RMSEA}=.018 ; \mathrm{SRMR}=.018$ ). 
The standardized solution, with beta coefficients shown in Figure 1, showed that the factors with greatest association with substance use were tobacco and alcohol use, while tobacco had a greatest association with alcohol use $(\beta=.49)$ and alcohol use had the greatest association with illicit drugs use $(\beta=.42)$. Tobacco use was also strongly associated with illicit drugs use $(\beta=.36)$. School satisfaction was negatively associated with tobacco and alcohol use ( $\beta=-.22$ and $\beta=-.27$, respectively). The disturbance values of each factor were .94 for tobacco, .73 for alcohol and, .73 for illicit drugs use.

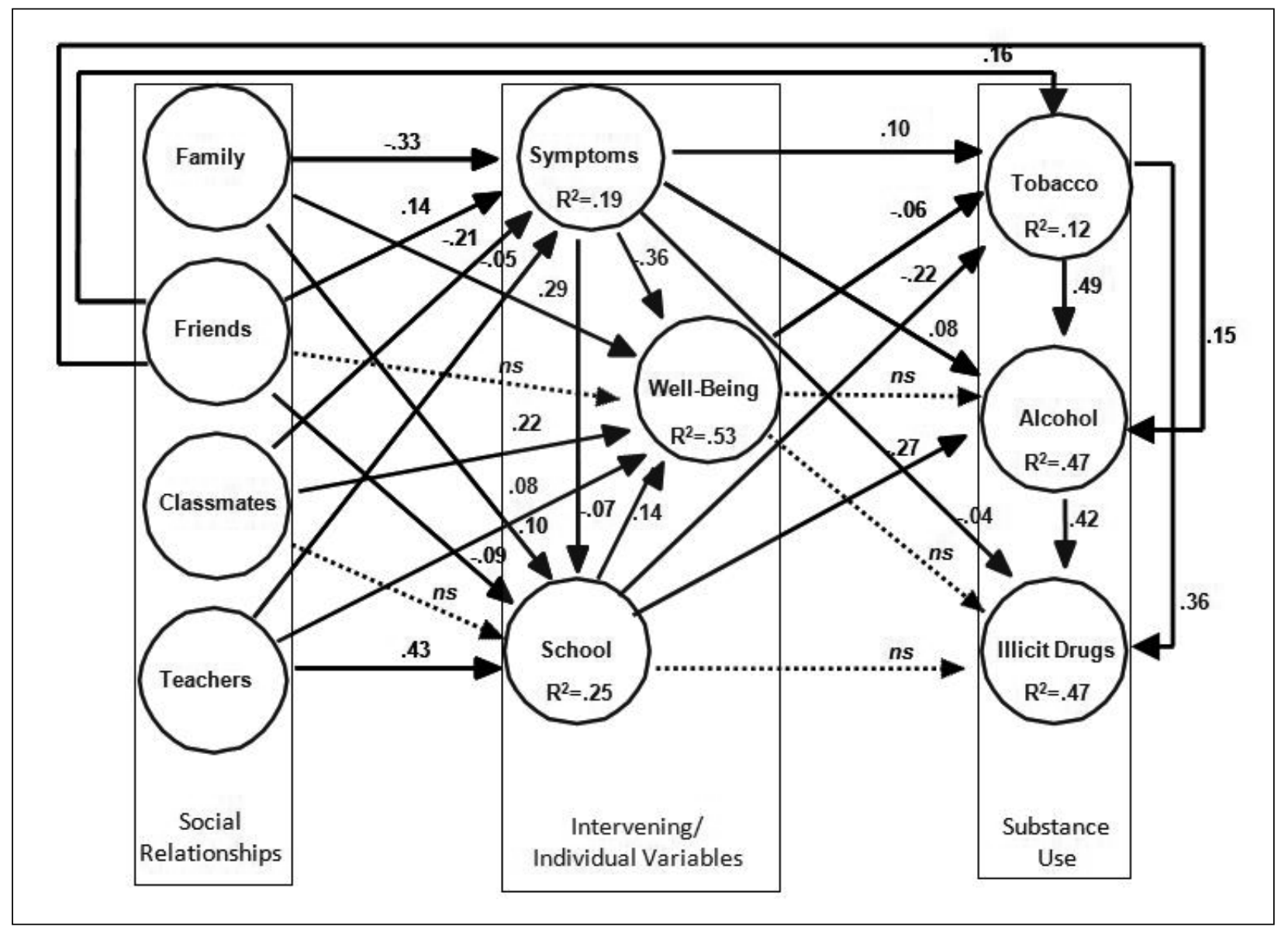

Figure 1. Substance use explanatory model with the full sample, $N=12881$.

Note. Only structural paths are represented in the figure.

For the intervening factors, psychological symptoms was associated with family communication $(\beta=-.33)$ and classmates $(\beta=-.21)$. Subjective well-being was associated with psychological symptoms $(\beta=-.36)$, family communication $(\beta=.29)$, and classmates $(\beta=.22)$. It appears that fewer psychological symptoms and better relationships with the family and the classmates are associated with well-being. Relationship with teacher was associated with school satisfaction $(\beta=.43)$.

Other significant paths were identified, including psychological symptoms with substance use $(\beta=.10$, for tobacco, $\beta=.08$, for alcohol, $\beta=-.04$ for illicit drugs), friends with tobacco and alcohol use ( $\beta=.16$ and $\beta=.15$, respectively), and well-being with tobacco use $(\beta=-.06)$. For intervening factors, significant paths included psychological symptoms with friends $(\beta=.14)$ and teachers ( $\beta=-.05)$; subjective well-being with teachers $(\beta=.08)$; and finally, friends, psychological symptoms, and family with school satisfaction ( $\beta=-.09, \beta=-.07, \beta=.10$, respectively). The disturbance values for the intervening factors were .90 for psychological symptoms, .69 for subjective well-being, and .87 for school satisfaction.

The explained variance of the relationships shown in Figure 1 was $12 \%$ for tobacco and $47 \%$ for alcohol and illicit drugs. Psychological symptoms, subjective well-being, school satisfaction and friends explain $12 \%$ of the variance on tobacco use factor. For alcohol use, tobacco use, psychological symptoms, school satisfaction, and friends explained $47 \%$ of the variance on this factor. This same amount of explained variance was account to illicit drug use factor in this case through the impact of tobacco use, alcohol use and psychological symptoms. For intervening factors, family, friends, classmates, and teachers factors explained $19 \%$ of the variance in psychological symptoms, $53 \%$ of the variance in subjective well-being and $25 \%$ of the variance in school satisfaction. 
Simões, C., Matos, M. G., Batista-Foguet, J. M. \& Simons-Morton, B. (2014). Substance Use Across Adolescence: Do Gender and Age Matter?

Factorial Invariance between Groups

The fit indices held in the "independent latent factors" and "intervening latent factors" models (unconstrained and constrained) for the four groups (CFI $>.98$; RMSEA $<.02$; $\Delta \mathrm{CFI} \leq .01$ ), which confirmed the presence of configural and metric invariance between the groups for these measurement models (see Table 1). The same wasn't verified for the "dependent latent factors model". The CFI difference between the unconstrained and constrained models was .047 , which means that metric invariance wasn't verified for the four groups in this measurement model. The next step was to compare the groups two by two. These analyses showed there was configural and metric invariance between younger boys and older boys groups, as well as between older boys and older girls groups. For the comparisons between younger boys and younger girls as well as for the younger girls and older girls we found configural invariance, but not metric invariance since the CFI difference between the two models (unconstrained and constrained) was greater than .01 (see Table 2). Nevertheless, the comparisons between the structural part of the model were undertaken for the four groups, considering the position of some authors that refer as a sufficient condition verify factorial invariance in a part of the indicators (Byrne, Shavelson, \& Muthén, 1989, cited in Billiet, Cambré, \& Welkenhuysen-Gybels, 2002). To undertake the comparisons between the structural part of the model, the three constraints imposed in the dependent model were released (spirits consumption and been drunk for alcohol factor, and illicit drug use last month in the illicit drugs use factor).

Table 1

Measurement Models Fit Indexes for the Four Groups

\begin{tabular}{lccc}
\hline & CFI $^{\mathrm{a}}$ & $\chi^{2}(d f)^{\mathrm{b}}$ & RMSEA $(90 \% \text { C.I. })^{\mathrm{a}}$ \\
\hline Independent latent factors model & & & \\
$\quad$ Unconstrained & .990 & $224.04^{*}(84)$ & $.011(.010-.013)$ \\
$\quad$ Constrained & .980 & $383.15^{*}(99)$ & $.015(.013-.017)$ \\
Intervening latent factors model & & & \\
$\quad$ Unconstrained & .988 & $175.56^{*}(40)$ & $.016(.014-.018)$ \\
$\quad$ Constrained & .985 & $225.09^{*}(52)$ & $.016(.014-.019)$ \\
Dependent latent factors model & & & \\
$\quad$ Unconstrained & .992 & $54.48^{*}(24)$ & $.010(.006-.013)$ \\
$\quad$ Constrained & .945 & $249.54^{*}(33)$ & $.023(.020-.025)$ \\
\hline
\end{tabular}

Note: ${ }^{\mathrm{R}}$ Robust; ${ }^{\mathrm{b}}$ Scaled Chi-Square.

$* p<.001$.

Table 2

Dependent Measurement Model Fit Indexes (Two by Two Comparisons)

\begin{tabular}{lccc}
\hline & $\mathrm{CFI}^{\mathrm{a}}$ & $\chi^{2}(d f)^{\mathrm{b}}$ & RMSEA (90\% C.I. $)^{\mathrm{a}}$ \\
\hline $\begin{array}{l}\text { Younger Boys- Younger Girls } \\
\quad \text { Unconstrained }\end{array}$ & .996 & $17.20(12)$ & $.007(.000-.014)$ \\
$\quad$ Constrained & .956 & $77.24^{*}(15)$ & $.022(.017-.027)$ \\
Older Boys- Older Girls & & & \\
$\quad$ Unconstrained & .991 & $45.40^{*}(12)$ & $.025(.017-.033)$ \\
$\quad$ Constrained & .988 & $60.53^{*}(15)$ & $.026(.019-.033)$ \\
Younger Boys- Older Boys & & & $.019(.012-.026)$ \\
$\quad$ Unconstrained & .990 & $37.30^{*}(12)$ & $.020(.014-.026)$ \\
$\quad$ Constrained & .986 & $50.90^{*}(15)$ & $.008(.000-.016)$ \\
Younger Girls - Older Girls & & & $.036(.031-.042)$ \\
$\quad$ Unconstrained & .997 & $17.31(12)$ & \\
$\quad$ Constrained & .916 & $147.73^{*}(15)$ & \\
\hline
\end{tabular}

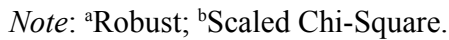

$* p<.001$. 
The Table 3 presents the factor loadings for the four groups in each measurement model. In general, all factor loadings are above .60. The factor loading of "health" in- dicator (subjective well-being factor) was lower, but above .40. Also the factor loadings of the indicator "classmates enjoy being together" were only slightly above .40 , except for the older boys group (.71).

Table 3

Factor Loadings ( $\lambda$ ) of the Ten Factors Indicators in the Model for Each of the Four Groups

\begin{tabular}{|c|c|c|c|c|c|}
\hline \multirow[t]{2}{*}{ Factor } & \multirow[t]{2}{*}{ Indicator } & $\begin{array}{c}\text { Younger } \\
\text { Boys }\end{array}$ & $\begin{array}{l}\text { Older } \\
\text { Boys }\end{array}$ & $\begin{array}{c}\text { Younger } \\
\text { Girls }\end{array}$ & $\begin{array}{l}\text { Older } \\
\text { Girls }\end{array}$ \\
\hline & & $\lambda$ & $\lambda$ & $\lambda$ & $\lambda$ \\
\hline \multirow[t]{2}{*}{ Family } & Father communication & .794 & .805 & .745 & .731 \\
\hline & Mother communication & .689 & .699 & .652 & .595 \\
\hline \multirow[t]{2}{*}{ Friends } & Same gender friends communication & .726 & .739 & .586 & .650 \\
\hline & Opposite gender friends communication & .708 & .722 & .726 & .710 \\
\hline \multirow[t]{3}{*}{ Classmates } & Enjoy being together & .429 & .710 & .416 & .449 \\
\hline & Are kind and helpful & .683 & .704 & 648 & 673 \\
\hline & Accept me as I am & .741 & .662 & .763 & .737 \\
\hline \multirow[t]{2}{*}{ Teachers } & Help when I need & .638 & .678 & .606 & .667 \\
\hline & Are interested in me as person & .722 & .637 & 648 & .603 \\
\hline \multirow[t]{3}{*}{ Psychological Symptoms } & Feeling low & .545 & .646 & .637 & .676 \\
\hline & Irritability or bad temper & .705 & .680 & .705 & .705 \\
\hline & Nervous & .625 & .667 & .601 & .650 \\
\hline \multirow[t]{2}{*}{ Subjective Well-Being } & Health & .407 & .471 & .435 & .428 \\
\hline & Happiness & .724 & .637 & .729 & .696 \\
\hline \multirow[t]{2}{*}{ School } & Feel about school & .701 & .637 & .751 & .763 \\
\hline & School is boring & .686 & .776 & .668 & .672 \\
\hline Tobacco & Frequency & 1.000 & 1.000 & 1.000 & 1.000 \\
\hline \multirow[t]{3}{*}{ Alcohol } & Beer consumption & .705 & .716 & .704 & .677 \\
\hline & Spirits consumption & .707 & .670 & .796 & .599 \\
\hline & Been drunk & .809 & .828 & .628 & .840 \\
\hline \multirow[t]{2}{*}{ Illicit Drugs Use } & Tried marijuana: & .696 & .853 & .786 & .906 \\
\hline & Illicit drug use last month & .712 & .811 & .713 & .749 \\
\hline
\end{tabular}

\section{Structural Model Multi-group Comparison}

The fit indices held in the analysis for the four groups (unconstrained and constrained models) were good: CFI varied between .973 (unconstrained model for younger boys/younger girls comparison and unconstrained model for younger boys/older boys comparison) and .956 (constrained model for younger girls/older girls comparison); RMSEA varied between .014 (.012-.015; unconstrained model for younger boys/younger girls comparison) and .020 (.019-.022; constrained model for older boys/older girls comparison). The group comparisons indicated that the model is invariant $(\Delta \mathrm{CFI}<=.01)$ in the two gender comparisons (younger boys-younger girls and older boysolder girls) and in one age comparison (younger boys-older boys). In the comparison between younger girls and older girls the difference between the CFI of constrained and unconstrained model was slightly larger than $.01(\Delta \mathrm{CFI}$ $=.014$ ), which imposed some reservations on the assumption of metric invariance between these two groups. Although the model is invariant between the groups, some 
Simões, C., Matos, M. G., Batista-Foguet, J. M. \& Simons-Morton, B. (2014). Substance Use Across Adolescence: Do Gender and Age Matter?

parameters (paths between factors) were non-invariant. Table 4 shows the non-invariant paths between the four comparisons in study (only non-invariant paths with significance level below .01 were considered).

For gender comparisons, the five paths were non-invariant in the two comparisons (younger boys-younger girls; older boys-older girls), include the paths between family and symptoms; school and alcohol; friends and symptoms; tobacco and alcohol; and school and well-being. The negative association between family and symptoms was greater for girls ( $B=-.33$ for younger girls, $B=-.47$ for older girls; $B=-.10$ for younger boys, $B=-.18$ for older boys), as was the association between friends and symptoms $(B=.24$ for younger girls, $B=.25$ for older girls; $B=.07$, for younger boys, $B=.02$ for older boys), and between school and well-being ( $B=.12$ for younger girls, $B=.10$ for older girls; $B=$ .08 , for younger boys, $B=.04$ for older boys). Conversely, the negative association between school and alcohol $(B=$ -.24 for younger boys, $B=-.31$ for older boys; $B=-.14$ for younger girls, $B=-.15$ for older girls) and the positive association between tobacco and alcohol $(B=.45$ for younger boys, $B=.37$ for older boys; $B=.27$ for younger girls, $B=$ .28 for older girls) were greater for the boys. Other paths appeared to be non-invariant in one-group comparison. The positive association between friends and alcohol was greater among girls than boys, but only in the younger group comparison $(B=.08$, for younger boys; $B=.16$ for younger girls). Also the association of classmates and symptoms was greater for girls ( $B=-.29$, for girls; $B=-.11$ for boys), while the association between symptoms and alcohol was larger for the boys ( $B=.24$ for boys; $B=.06$ for girls), but significant only among older boys and older girls.

There were four non-invariant paths in the two age group comparison (See Table 4$)$. The positive association between alcohol and drugs $(B=.59$ for older boys, $B=.66$ for older girls; $B=.39$ for younger boys, $B=.23$ for younger girls), the positive association between friends and tobacco ( $B=.46$ for older boys, $B=.65$ for older girls; $B=.07$ for younger boys, $B=.16$ for younger girls) and the positive association between symptoms and tobacco $(B=.33$ for older boys, $B=.19$ for older girls; $B=.10$ for younger boys, $B=.08$ for younger girls) were greater in the older than younger groups. The other non-invariant path in the two age groups comparisons were the association of classmates and well-being that were greater in younger than older groups $(B=.35$ for younger boys, $B=.25$ for younger girls; $B=.13$ for older boys, $B=.11$ for older girls). Like with gender comparisons, other paths appeared to be non-invariant, but only in one group comparison. The positive association of friends and symptoms $(B=.07$, for younger boys; $B=-.02$ for older boys) and the negative association of classmates and symptoms $(B=-.31$, for younger boys; $B=-.11$ for older boys) were greater in the younger group, but only in the younger boys-older boys comparison. The negative association of symptoms and school $(B=-.09$, for younger girls; $B=-.04$ for older girls) was greater for younger than older girls. The positive association between friends and alcohol was greater in older than younger boys
( $B=.25$, for older boys; $B=.08$ for younger boys) and the negative association of school on tobacco was greater for older than younger girls ( $B=-.48$, for older girls; $B=-.19$ for younger girls).

\section{Discussion}

In this paper we reported the relationships between social relationships, psychological variables, and substance use based on the full sample. Then we examined age and gender subgroup relationships.

The proposed model shown in Figure 1 provided useful information about associations between social context variables, intervening individual-level variables, and substance use, supporting the hypothesis proposed by Igra and Irwin (1966) that the influence of social contexts on substance use is mediated by individual variables.

The findings that tobacco and alcohol use were highly associated with illicit drugs use has been shown in other studies (Cardenal \& Adell, 2000; Simões, 2007). Our finding that the variable, psychological symptoms, was positively associated with tobacco and alcohol use, is consistent with the notion that adolescents may sometimes use substances for relief from psychological symptoms (Matos, Gaspar, Vitória, \& Clemente, 2003; Simões, 2007). However, the significant negative association between psychological symptoms and illicit drugs suggests that these substances may be used to have fun and not necessarily to cope with negative symptoms (Braconnier \& Marcelli, 2000). Nevertheless, it is important to emphasize that the association between psychological symptoms and substance use didn't show a great magnitude, especially in the case of illicit drugs use. Subjective well-being show a small negative association with tobacco use, but this association was not significant for the other types of substance, unlike in other research (Griffin, Botvin, Scheier, Epstein, $\&$ Doyle, 2002), calling into question the role of subjective well-being as a mediator variable between social contexts and substance use. School satisfaction was negatively associated but only with tobacco and alcohol use, consistent with other research suggesting that school can be protective against substance use (Simões et al., 2012). In addition, relationships with friends was directly and positively associated with tobacco and alcohol use. Several studies have shown associations between adolescent substance use and affiliation with peer substance use and positive attitudes and expectations, for, and acceptance of, substance use (Simões, 2007). The relationships between substance use and family, classmates, and teachers appeared to be work mainly through their association with intervening factors, suggesting the importance of social relationships (Huver et al., 2007; Pattussi, Moyses, Junges, \& Sheiham, 2006). Consistent with other findings (Greeff \& le Roux, 1999; Weitoft et al., 2003), the relationships between family and classmates with substance use were mainly through their negative associations with psychological symptoms. Teachers contribution to substance use was through association with school satisfaction, as found previously by Simões (2007). 
Psicologia: Reflexão e Crítica, 27(1), 179-188.

Table 4

Non-Invariant Paths in Gender and Age Group Comparisons

\begin{tabular}{|c|c|c|c|c|c|}
\hline \multirow[b]{2}{*}{ Comparison } & \multirow[b]{2}{*}{ Groups } & \multirow[b]{2}{*}{ Path } & \multirow[b]{2}{*}{$\chi^{2}$} & \multicolumn{2}{|c|}{$B$} \\
\hline & & & & Boys & Girls \\
\hline \multirow[t]{6}{*}{ Gender } & \multirow{6}{*}{$\begin{array}{l}\text { Younger Boys } \\
\text { Younger Girls }\end{array}$} & Family - Symptoms & $34.17 * * *$ & $-.10^{*}$ & $-.33 *$ \\
\hline & & School - Alcohol & $27.07 * * *$ & $-.24 *$ & $-.14 *$ \\
\hline & & Friends - Symptoms & $15.77 * * *$ & $.07 *$ & $.24 *$ \\
\hline & & Tobacco - Alcohol & $12.24 * * *$ & $.45^{*}$ & $.27 *$ \\
\hline & & Friends - Alcohol & $9.12 * *$ & $.08 *$ & $.16^{*}$ \\
\hline & & School - Well-Being & $6.58 * *$ & $.08 *$ & $.12 *$ \\
\hline \multirow[t]{7}{*}{ Gender } & \multirow{7}{*}{$\begin{array}{l}\text { Older Boys } \\
\text { Older Girls }\end{array}$} & Symptoms - Alcohol & $20.99 * * *$ & $.24 *$ & $.06^{*}$ \\
\hline & & Family - Symptoms & $18.00 * * *$ & $-.18 *$ & $-.47 *$ \\
\hline & & Friends - Symptoms & $16.09 * * *$ & .02 & $.25 *$ \\
\hline & & School - Alcohol & $11.89 * * *$ & $-.31 *$ & $-.15^{*}$ \\
\hline & & Tobacco - Alcohol & $7.45 * *$ & $.37^{*}$ & $.28 *$ \\
\hline & & Classmates - Symptoms & $7.05 * *$ & $-.11 *$ & $-.29 *$ \\
\hline & & School - Well-Being & $6.76^{* *}$ & $.04 *$ & $.10 *$ \\
\hline \multirow{2}{*}{ Comparison } & \multirow{2}{*}{ Groups } & \multirow{2}{*}{ Path } & \multirow{2}{*}{$\chi^{2}$} & \multicolumn{2}{|c|}{$B$} \\
\hline & & & & Boys & Girls \\
\hline \multirow[t]{7}{*}{ Age } & \multirow{7}{*}{$\begin{array}{l}\text { Younger Boys } \\
\text { Older Boys }\end{array}$} & Friends - Tobacco & $38.68 * * *$ & $.07 *$ & $.46^{*}$ \\
\hline & & Alcohol - Illicit Drugs & $22.98 * * *$ & $.39 *$ & $.59 *$ \\
\hline & & Classmates - Well-Being & $18.94 * * *$ & $.35^{*}$ & $.13^{*}$ \\
\hline & & Symptoms - Tobacco & $14.75 * * *$ & $.10 *$ & $.33 *$ \\
\hline & & Friends - Symptoms & $11.66^{* * *}$ & $.07 *$ & -.02 \\
\hline & & Friends - Alcohol & $8.36^{* *}$ & $.08 *$ & $.25 *$ \\
\hline & & Classmates - Symptoms & $6.97 * *$ & $-.31 *$ & $-.11 *$ \\
\hline \multirow[t]{6}{*}{ Age } & \multirow{6}{*}{$\begin{array}{l}\text { Younger Girls } \\
\text { Older Girls }\end{array}$} & Alcohol - Illicit Drugs & $44.41 * * *$ & $.23 *$ & $.66^{*}$ \\
\hline & & Friends - Tobacco & $32.25 * * *$ & $.16^{*}$ & $.65 *$ \\
\hline & & School - Tobacco & $27.34 * * *$ & $-.19 *$ & $-.48 *$ \\
\hline & & Classmates - Well-Being & $8.90 * *$ & $.25^{*}$ & $.11 *$ \\
\hline & & Symptoms - School & $8.27 * *$ & $-.09 *$ & $-.04^{*}$ \\
\hline & & Symptoms - Tobacco & $7.16^{* *}$ & $.08 *$ & $.19 *$ \\
\hline
\end{tabular}

Note. $B=$ Non-standardized.

$* p<.05 ; * * p<.01 ; * * * p<.001$.

Subgroup analyses showed that relationships among the variables varied among boys and girls. Notably, the associations between family and friends with symptoms and school with subjective well-being were greater for girls, while associations between school and alcohol and between tobacco and alcohol were greater for boys than girls. Particularly, the association between friends and alcohol was greater for younger girls than younger boys, and the association of classmates with symptoms was greater for older girls compared with older boys. The association between symptoms and alcohol was different between boys and girls, but only in older groups. Family, friends, and classmates were more strongly associated with psychological symptoms for girls than boys, consistent with the literature on the relatively greater vulnerability of girls than boys' contexts (Oldenburg \& Kerns, 1997; Rudolph \& Hammen, 1999). Similarly, we found that school was associated with alcohol use, especially 
Simões, C., Matos, M. G., Batista-Foguet, J. M. \& Simons-Morton, B. (2014). Substance Use Across Adolescence: Do Gender and Age Matter?

for boys, and with subjective well-being, especially for girls, as found by others (Matos et al., 2000). Friends were positively associated with alcohol use, especially for younger girls, consistent with the finding of (Carli, 1989) that younger girls are more vulnerable to peer influence. The finding that psychological symptoms were associated with substance use, especially for older boys, is consistent with other research (Braconnier \& Marcelli, 2000; Matos et al., 2003).

The findings results suggested that friends and symptoms increased the risk for tobacco use, especially for older adolescents. Relationships with classmates were associated to well-being mainly among younger adolescents. Also, the association between friends and classmates with symptoms was greater in younger than older boys. Similarly, the association of symptoms with school was greater in younger than older girls. Relationships with friends were more strongly associated with alcohol in older male adolescents, while the association between school and tobacco was greater in older female adolescents. The relationship between friends and risk behaviours has been found to be greater among older adolescents (Matos et al., 2006).

\section{Implications for Practice}

Our findings support the need to improve the social contexts of adolescents as a means of improving well-being and preventing substance use problems. School, family, and friends can increase or decrease risk, mainly through their effects on mental health, well-being, and school adjustment. However, associations vary by age and sex, suggesting that prevention activities should consider these important developmental considerations.

Since tobacco seems to be a gateway to alcohol use and alcohol use a gateway to other substances, as well as tobacco, it is extremely important to prevent these behaviors. In this scope, several measures had been taken in the last years. Besides the implementation, in the last years, of legal restrictions in access to tobacco and alcohol to adolescents and more restricted rules in the schools, it is important to emphasize that substance use is one of the priority intervention areas in health promotion at Portuguese schools (Working Group on Sexual Education and Health Education, Ministry of Education [GTES/ME], 2007). These interventions (universal and selective) aim to develop personal and social competences and skills to better cope with life events in order to promote health behaviours and prevent risk behaviours, like substance use (Matos et al., 2006).

\section{Strengths and Limitations}

The findings should be interpreted within the limitations of the study, which include its cross-sectional design and potential error or bias from self-report. Notwithstanding these limitations, this study used a large sample of adolescents and the sampling procedures helped to ensure a nationally representative sample of school-aged adolescents in the $6^{\text {th }} 8^{\text {th }}$ and $10^{\text {th }}$ grades. This study doesn't encompass adolescents that had dropout school, which might be in greater risk to substance use (Simões, 2007).

\section{References}

Argyle, M. (1997). Is happiness a cause of health? Psychology and Health, 12, 769-781.

Beauvais, F., \& Oetting, E. R. (1999). Drug use, resilience, and the myth of golden child. In M. D. Glantz \& J. L. Johnson (Eds.), Resilience and development: Positive life adaptations (pp. 101-107). New York: Klumer Academic.

Bentler, P. M. (1995). EQS Structural Equations Program Manual. Encino, CA: Multivariate Software.

Billiet, J., Cambré, B., \& Welkenhuysen-Gybels, J. (2002). Equivalence of measurement instruments for attitude variables in comparative surveys, taking methods effects into account: The case of ethnocentrism. In A. Ferligoj \& A. Mrvar (Eds.), Developments in Social Science Methodology (Vol. 18, pp. 53-72). Ljubljana, Slovenia: FDV.

Borges, A., Matos, M. G., \& Diniz, J. A. (2011). Processo adolescente e saúde positiva: Âmbitos afectivo e cognitivo. Psicologia: Reflexão e Crítica, 24(2), 281-291. Recuperado em http://www.scielo.br/scielo.php?script=sci arttext\&pid=S0102-79722011000200009\&lng=en\&tlng=pt

Braconnier, A., \& Marcelli, D. (2000). As mil faces da adolescência. Lisboa, Portugal: Climepsi.

Cardenal, C. A., \& Adell, M. N. (2000). Factors associated with problematic alcohol consumption in schoolchildren. Journal of Adolescent Health, 27(6), 425-433.

Carli, L. L. (1989). Gender differences in interaction style and influence. Journal of Personality and Social Psychology, 56(4), 565-576.

Coleman, J. C. (1985). Psicología de la adolescencia. Madrid, España: Morata.

Currie, C., Gabhainn, S. N., Godeau, E., Roberts, C., Smith, R., Currie, D., ...Barnekow, V. (2008). HBSC international report from the 2005/2006 survey: Inequalities in young people's health. Copenhagen, Denmark: World Health Organization.

Currie, C., Smith, R., Boyce, W., \& Smith, R. (2001). HBSC, a WHO cross national study: Research protocol for the 2001/2002 survey. Copenhagen, Denmark: World Health Organization.

Dahl, R. E. (2004). Adolescent brain development: A period of vulnerabilities and opportunities. Annals for the New York Academy of Sciences, 102, 1-22.

D‘Amico, E. J., Ellickson, R. L., Wagner, E. F., Turrisi, R., Fromme, K., Ghosh-Dastidar, B., ...Wright, D. (2005). Developmental considerations for substance use interventions from middle school through college. Alcoholism: Clinical and Experimental Research, 29(3), 474-483.

Feitosa, F. B., Matos, M. G., Del Prette, Z. A. P., \& Del Prette, A. (2005). Suporte social, nível socioeconômico e o ajustamento social e escolar de adolescentes portugueses. Temas em Psicologia, 13(2), 129-138.

Greeff, A. P., \& le Roux, M. C. (1999). Parents` and adolescents perceptions of a strong family. Psychological Reports, 84(3, Pt. 2), 1219-1224.

Griffin, K. W., Botvin, G. J., Scheier, L. M., Epstein, J. A., \& Doyle, M. M. (2002). Personal competence skills, distress, and well-being as determinants of substance use in a predominantly minority urban adolescent sample. Prevention Science, 3(1), 23-33. 
Grogan, S., Conner, M., Fry, G., Gough, B., \& Higgins, A (2009). Gender differences in smoking: A longitudinal study of beliefs predicting smoking in 11-15 year olds. Psychology \& Health, 24(3), 301-316.

Hibell, B., Guttormsson, U., Ahlström, S., Balakireva, O., Bjarnason, T., Kokkevi, A., ...Weihe, P. (2009). The 2007 ESPAD Report - Substance Use Among Students in 35 European Countries. Stockholm, Sweden: The Swedish Council for Information on Alcohol and Other Drugs.

Huver, R. M. E., Engels, R. C. M. E., Van Breukelen, G., \& de Vries, H. (2007). Parenting style and adolescent smoking cognitions and behaviour. Psychology \& Health, 22(5), 575-593.

Igra, V., \& Irwin, C. E., Jr. (1996). Theories of adolescent risktaking behavior. In R. J. DiClemente, W. B. Hansen, \& L. E. Ponton (Eds.), Handbook of Adolescent Health Risk Behavior (pp. 35-51). New York: Plenum Press.

Matos, M. G., \& Equipa do Projecto Aventura Social. (2003). A saúde dos adolescentes portugueses (Quatro anos depois). Lisboa, Portugal: Faculdade de Motricidade Humana, Universidade Técnica de Lisboa.

Matos, M. G., Gaspar, T., Vitória, P. D., \& Clemente, M. P. (2003). Adolescentes e o tabaco: Rapazes e raparigas. Lisboa, Portugal: Faculdade de Motricidade Humana, Universidade Técnica de Lisboa.

Matos, M. G., Simões, C., Carvalhosa, S. F., Reis, C., \& Canha, L. (2000). A saúde dos adolescentes portugueses: Estudo nacional da rede europeia HBSC / OMS (1998). Lisboa, Portugal: Faculdade de Motricidade Humana, Universidade Técnica de Lisboa.

Matos, M. G., Simões, C., Tomé, G., Gaspar, T., Camacho, I., Diniz, J. A., ...Equipa do Projecto Aventura Social. (2006). A saúde dos adolescentes portugueses: Hoje em 8 anos Recuperado em 20 dezembro, 2006, de http://www.fmh.utl.pt/ aventurasocial/pdf/191206/nacional.pdf

Oldenburg, C. M., \& Kerns, K. A. (1997). Associations between peer relationships and depressive symptoms: Testing moderator effects of gender and age. Journal of Early Adolescence, 17(3), 319-337.

Otten, R., Van de Ven, M. O. M., Engels, R. C. M. E., \& Van den Eijnden, R. J. J. M. (2009). Depressive mood and smoking onset: A comparison of adolescents with and without asthma. Psychology \& Health, 24(3), 287-300.

Pattussi, M., Moyses, S., Junges, J., \& Sheiham, A. (2006). Capital social e a agenda de pesquisa em epidemiologia. Cadernos de Saúde Pública, 2(8), 1525-1546.

Reise, S. P., Widaman, K. F., \& Pugh, R. H. (1993). Confirmatory factor analysis and item response theory: Two approaches for exploring measurement invariance. Psychological Bulletin, $114,552-566$.

Roberts, C., Tynjälä, J., Currie, D., \& King, M. (2004). Annex 1. Methods Young people's health in context: Health Behaviour in School-Aged Children (HBSC) study: International report from the 2001/2002 survey (pp. 217-227). Copenhagen, Denmark: World Health Organization Regional Office for Europe.

Rudolph, K. D., \& Hammen, C. (1999). Age and gender as determinants os stress exposure, generation, and reactions in youngsters: A transational perspective. Child Development, 70(3), 660-677.

Settertobulte, W. (2000). Family and peer relations. In C. Currie, K. Hurrelmann, W. Settertobulte, C. A. Smith, \& J. Todd (Eds.), Health and health behaviour among young people (pp. 39-48). Copenhagen, Denmark: World Health Organization.

Simões, C. (2007). Comportamentos de risco na adolescência [Risk behaviors in adolescence]. Lisboa, Portugal: Fundação Calouste Gulbenkian.
Simões, C., Matos, M. G., Moreno, M. C., Rivera, F., BatistaFoguet, J., \& Simons-Morton, B. (2012). Substance use in Portuguese and Spanish adolescents: Highlights from differences and similarities and moderate effects. Spanish Journal of Psychology, 15(3), 1024-1037.

Simons-Morton, B. G. (2007). Social influences on adolescent substance use. American Journal of Health Behavior, 31(6), 672-684.

Simons-Morton, B. G., \& Chen, R. (2009). Peer and parent influences on school engagement among early adolescents. Youth and Society, 41(1), 3-25.

Simons-Morton, B. G., Farhat, T., Ter Bogt, T. F., Hublet, A., Kuntsche, E., Nic Gabhainn, S., ...Health Behaviour in Schoolaged Children Risk Behaviour Focus Group. (2009). Gender specific trends in alcohol use: Cross-cultural comparisons from 1998 to 2006 in 24 countries and regions. International Journal of Public Health, 54(Suppl. 2), S199-S208.

Spijkerman, R., Van den Eijnden, R. J. J. M., Overbeek, G., \& Engels, R. C. M. E. (2007). The impact of peer and parental norms and behavior on adolescent drinking: The role of drinker prototypes. Psychology \& Health, 22(1), 7-29.

Sprinthall, N. A., \& Collins, W. A. (1999). Psicologia do adolescente: Uma abordagem desenvolvimentalista (2. ed.). Lisboa, Portugal: Fundação Calouste Gulbenkian.

Steinberg, L. (2001). The role of family in adolescent development: Preventing risk, promoting resilience. Retrieved November 15, 2001, from www.cyfernet.org

Tomé, G., Camacho, I., Matos, M. G., \& Diniz, J. A. (2011). A Influência da comunicação com a família e grupo de pares no bem-estar e nos comportamentos de risco nos adolescentes Portugueses. Psicologia: Reflexão e Crítica, 24(4). Recuperado em http://www.scielo.br/scielo.php?pid=S010279722011000400015\&script=sci_arttext

Torsheim, T., \& Wold, B. (2001). School-related stress, school support, and somatic complaints: A general population study. Journal of Adolescent Research, 16(3), 293-303.

Udry, J. R. (1994). Integrating biological and sociological models of adolescent problem behaviors. In R. D. Ketterlinus \& M. E. Lamb (Eds.), Adolescent problem behaviors: Issues and research (pp. 41-56). Mahwah, NJ: Laurance Erlbaum.

Weitoft, G. R., Hjern, A., Haglund, B., \& Rosen, M. (2003). Mortality, severe morbidity, and injury in children living with single parents in Sweden: A population-based study. Lancet, 361(9354), 289-295.

Werner, E. E., \& Smith, R. S. (2001). Journeys from childhood to midlife: Risk, resilience and recovery. New York: Cornell University Press.

Whalen, C. K., Jamner, L. D., Henker, B., \& Delfino, R. J. (2001). Smoking and moods in adolescents with depressive and aggressive dispositions: Evidence from surveys and electronic diaries. Health Psychology, 20(2), 99-111.

Working Group on Sexual Education and Health Education, Ministry of Education. (2007). Evaluation of health promotion in schools - Evaluation of GTES intervention 2004-2007. Internal paper developed for the Ministry of Education, Lisbon, Portugal. 